\title{
Reflexión sobre el significado SEMANA DEL MIGRANTE para UTEC

\section{RESUMEN}

Como centro educativo de nivel superior donde debe existir una reflexión y un debate permanente sobre el estado de la ciencia, no somos ajenos a la calidad de nuestro entorno ni mucho menos a las expectativas de nuestra gente, por ello consecutivamente cada año se celebra la "Semana del Migrante".

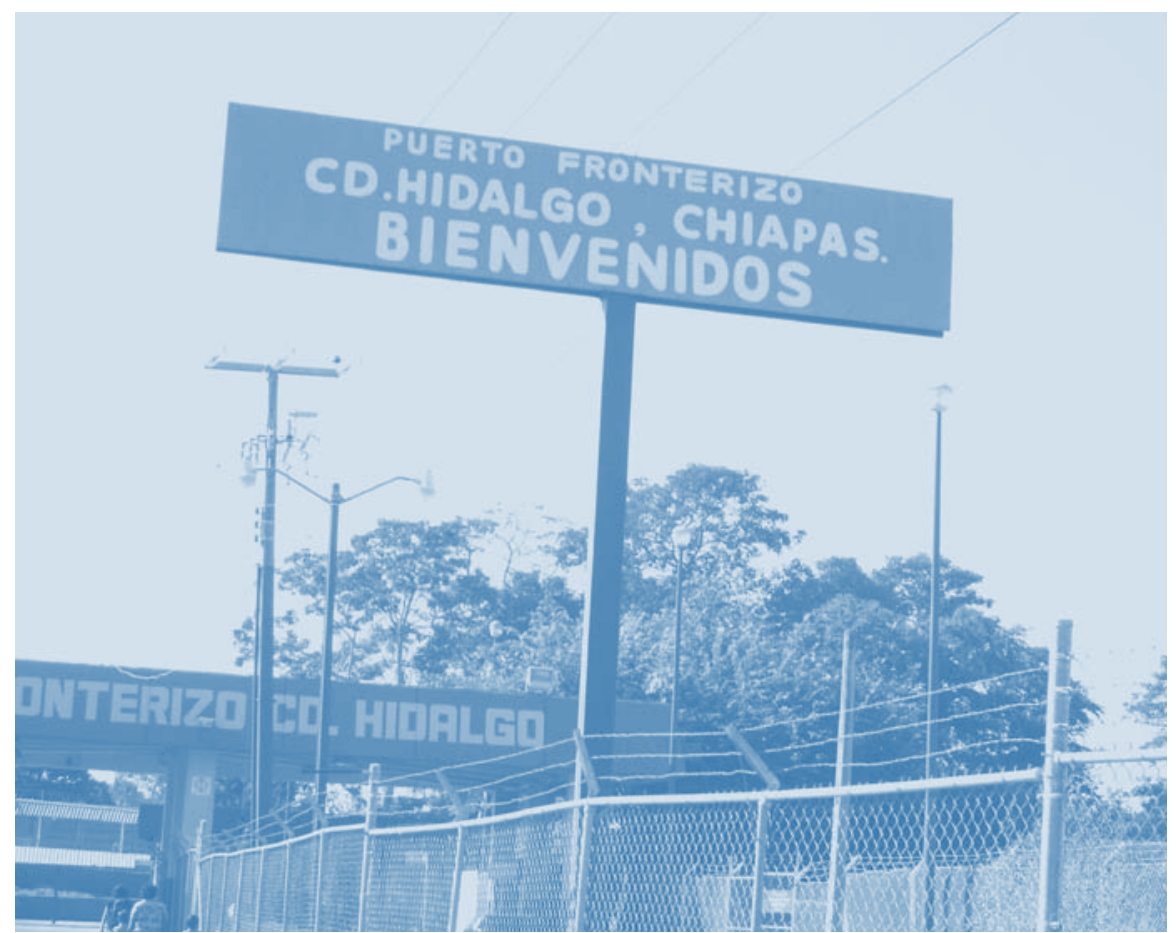

Una realidad

que merece una reflexión

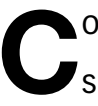

omprendemos que existe una crisis mundial pero no aceptamos que esa realidad externa sea el pretexto válido para justificar nuestra propia inacción e indiferencia como Estado y más específicamente como gobierno. Después del fin del conflicto y de la firma de los Acuerdos de Paz, la emigración motivada por la guerra ha continuado por razones del abandono, de la desesperación y del desencanto ante la ausencia de políticas concretas y efectivas para incidir en el nivel de vida

\footnotetext{
1 Artículo basado en el discurso de inauguración de la 5ª Semana del Migrante el 1 de septiembre 2010, en la Universidad Tecnológica de El Salvador.
} 
del pueblo, circunstancia que influye en la decisión de quedarse en el país por algo cierto y beneficioso, o bien, optar, con los riesgos del viaje e incertidumbre de integración a otras sociedades, a buscar la alternativa ante la falta de oportunidades locales que contribuyan a aliviar las ya precarias circunstancias de existencia de nuestros hermanos.

La migración es un fenómeno actual cuya presencia es aceptada, tolerada y hasta estimulada por gobiernos y sociedades que se benefician con el esfuerzo de los emigrantes, quienes vinculados con sus familias y lugares de asentamiento envían regularmente la ayuda familiar, las famosas remesas, las cuales se convierten en fuentes de ingresos que subsidian la baja productividad de los países por causas de las crisis de los modelos económicos y de las incapacidades de los gobernantes que dirigen nuestros países.

Todos conocemos que la vida en El Salvador es difícil. Existe una crisis que arrastramos desde hace más de 30 años, primero provocada por el conflicto interno y luego por las políticas erradas de privilegios para unos pocos y de marginación y olvido para los otros, a lo que se suman los inusitados niveles de corrupción nunca vistos y ni siquiera imaginados, todo lo cual, ha creado condiciones de vida extremadamente difíciles a la inmensa mayoría de salva-
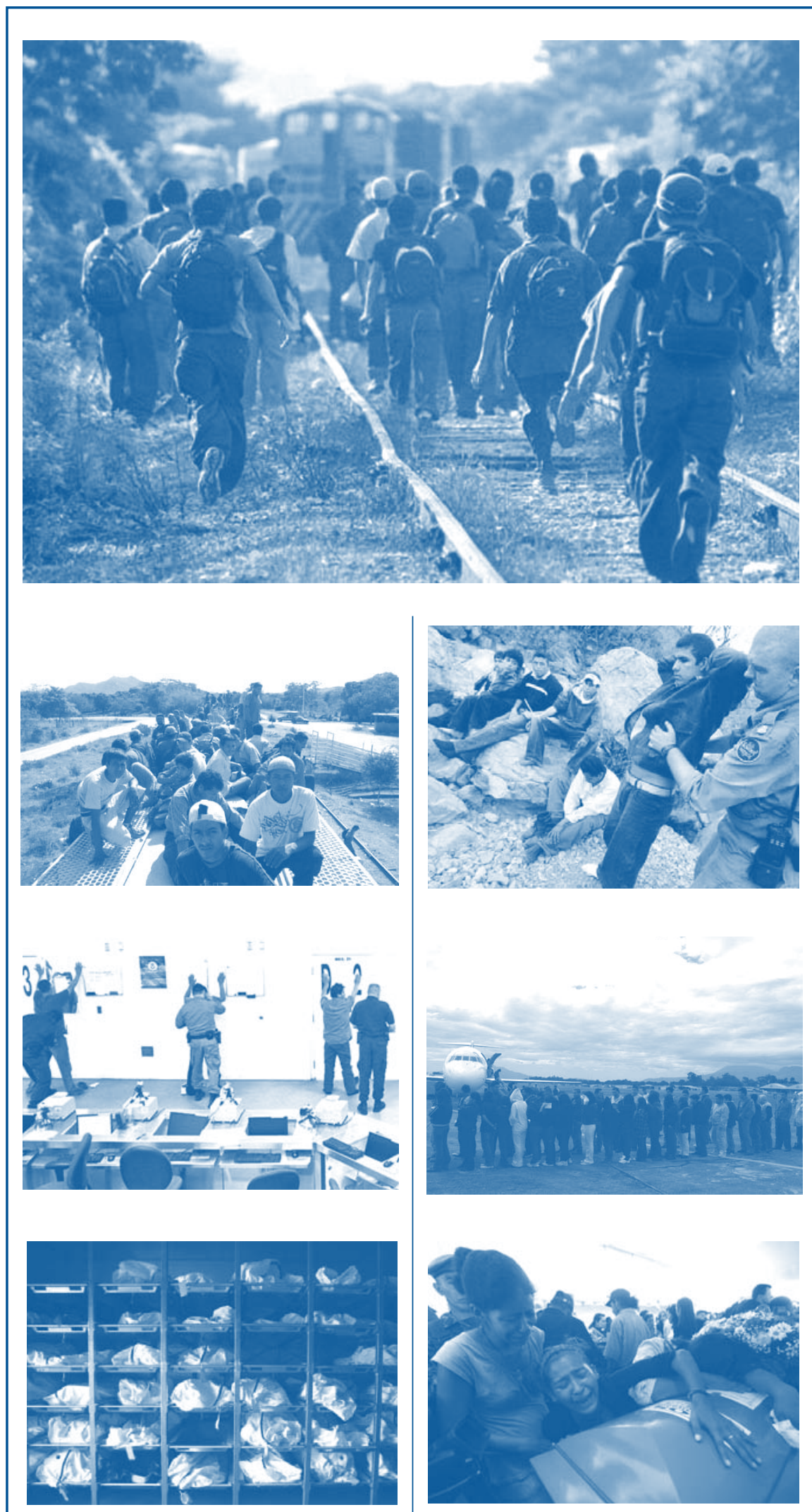
doreños. El déficit en las áreas de salud y de educación se ha agravado y con ello, el hambre, la pobreza y el desempleo han orillado a muchos a buscar en otros países la posibilidad de atender sus necesidades básicas de subsistencia.

Sin duda alguna nuestra población campesina y suburbana vive con grandes limitaciones, y aunque la causa aparente es la falta de empleo y los salarios indignos que devienen de su baja educación, debe señalarse que en la mayoría de nuestra población, esas graves limitaciones las provoca el desajuste entre los exiguos ingresos y la familia numerosa, lo cual reduce dramáticamente, mas allá de lo indispensable, el nivel de atención que cada uno requiere.

Al compararnos con otros países, encontramos que la solución pasa por la integración de las políticas públicas según las necesidades y particularidades de cada nación. Así, mientras El Salvador tiene una población de 7,185,218 y una densidad poblacional de 341.5 habitantes por kilómetro cuadrado, costa Rica tiene $4,253,877$ habitantes y 83.2 habitantes por kilómetro cuadrado, es decir que El Salvador necesita dos veces más escuelas, atención médica y empleos que las que tiene probablemente el hermano país centroamericano. Este desbalance entre recursos y habitantes, requiere con urgencia una política realista de población que sea congruente con las políticas de salud, educación, empleo y producción para lograr un desarrollo humano, justo y satisfactorio para todos.

Es el momento que el Estado asuma con responsabilidad la problemática de esta lacerante situación. No se puede continuar con la doble moral de alentar la emigración con la inacción en el campo de la formación laboral y del empleo, y luego lamentarse por los sufrimientos y vejámenes a que son sometidos nuestros nacionales.

Dentro de la pena y frustración que han causado las impactantes imágenes de la masacre de Tamaulipas y las consiguientes reacciones de dolor de sus familiares, con quienes somos solidarios como universidad, encontramos que la vigencia en el análisis de esta problemática debe continuar, es más, debe intensificarse, ya que como sociedad civil debemos conocer más ese fenómeno social para colaborar a enfrentarlo, puesto que su atención requiere acertadas e inmediatas decisiones políticas para resolverlo, a efecto de revertir lo que ya es una situación que demanda, no promesas ni declaraciones, sino hechos, que signifiquen un compromiso permanente de solución a favor de nuestros hermanos cercanos y lejanos. Necesitamos convertir a El Salvador en un país de derechos y oportunidades para que todos podamos vivir mejor.

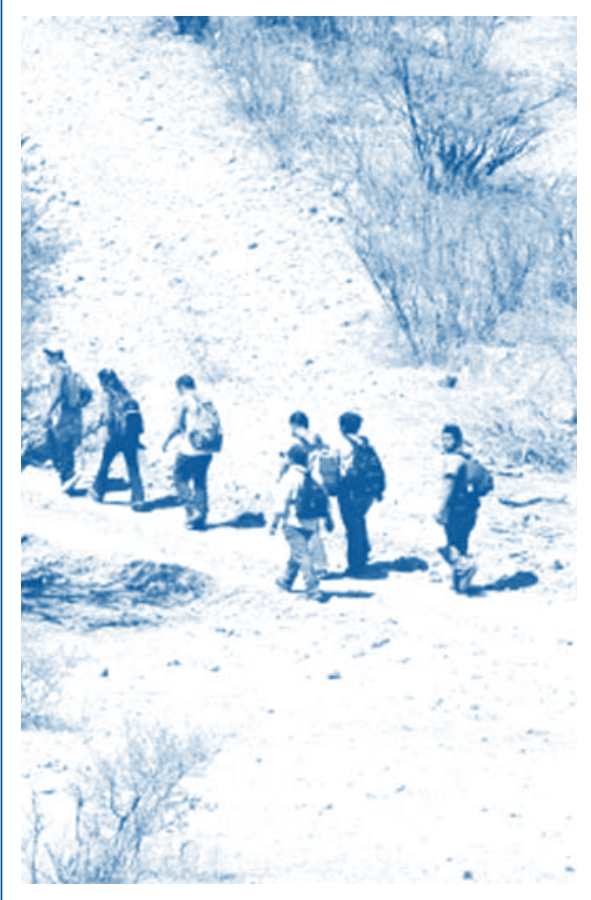

«EI déficit en las áreas de salud y de educación se ha agravado y con ello, el hambre, la pobreza y el desempleo han orillado a muchos a buscar en otros países la posibilidad de atender sus necesidades básicas de subsistencia. 97 